\title{
Inter-ethnic (In)tolerance between Turks and Kurds: Implications for Turkish Democratisation
}

\section{Zeki Sarigil \& Ekrem Karakoc}

To cite this article: Zeki Sarigil \& Ekrem Karakoc (2017) Inter-ethnic (In)tolerance between Turks and Kurds: Implications for Turkish Democratisation, South European Society and Politics, 22:2, 197-216, DOI: $10.1080 / 13608746.2016 .1164846$

To link to this article: https://doi.org/10.1080/13608746.2016.1164846

曲 Published online: 30 Mar 2016.

Submit your article to this journal $\widetilde{ }$

Џll Article views: 628

Q View related articles ¿

View Crossmark data $₫$

4 Citing articles: 3 View citing articles 진 


\title{
Inter-ethnic (In)tolerance between Turks and Kurds: Implications for Turkish Democratisation
}

\author{
Zeki Sarigil and Ekrem Karakoc
}

\begin{abstract}
Using public opinion survey data, this study investigates the determinants of inter-ethnic (in)tolerance among Turks and Kurds in Turkey. Our empirical analyses show that, compared with Turks, Kurds have a relatively higher level of tolerance towards the ethnic outgroup. Our findings also suggest that different dynamics and factors mould Turks' and Kurds' tolerance towards ethnic out-group members. Religiosity, (ethno)nationalist orientations, inter-ethnic contact, threat perception and economic factors are the most consistent variables shaping Turks' tolerance towards Kurds. In contrast, religion-related factors and inter-ethnic social contact do not have a statistically significant effect on Kurds' tolerance towards Turks. (Ethno)nationalist orientations, however, appear to reduce Kurds' tolerance.
\end{abstract}

\section{KEYWORDS}

Inter-ethnic (in)tolerance; religiosity; (ethno) nationalism; social contact; Kurdish conflict; Turkish democratisation

\section{Introduction}

This study examines inter-ethnic social tolerance in the Turkish context, between the dominant ethnic group, Turks, and the largest ethnic minority, Kurds. We believe that the Turkish case provides a quite timely context within which to investigate inter-ethnic relations. In the Turkish setting, Kurds constitute the second-largest ethnic group after Turks, making up 15-17 per cent of the total Turkish population. ${ }^{1}$ Turkey's Kurds, who are not officially recognised as a minority group, have been demanding certain cultural rights (e.g. speaking, publishing and broadcasting in Kurdish, public education in Kurdish, official status for the Kurdish language) and political rights (e.g. constitutional recognition of Kurdish ethnic identity and power-sharing arrangements such as decentralisation, regional autonomy or self-rule, translated as özerklik or öz yönetim) for decades. However, until the early 2000s, the Turkish state responded to these demands mostly with a policy of denial, suppression and assimilation (Yegen 2004, 2009). Not surprisingly, such state attitudes and policies triggered the rise of a Kurdish ethnonationalist movement. As widely analysed, the Kurdish ethnopolitical movement in both peaceful and violent forms has posed a major challenge to the Turkish state since the mid-1980s (e.g. see Bruinessen 2000; Gunter 2004; Yegen 2004, 2009; Marcus 2007; Watts 2010; Gunes 2012; Romano \& Gurses 2014; Aydin \& Emrence 2015). The Turkish state has been fighting against the Kurdish insurgent group, the Kurdistan Workers' Party (Partiya Karkaren Kurdistan - PKK) for the last three decades and the conflict has claimed around 40,000 lives (see Watts 2010, p. 22; Aydin \& Emrence 2015, p. 2). 
In the early 2000s, the Turkish state softened its attitude on the Kurdish issue. Finally recognising the ethnopolitical aspect of the problem, Turkish governments have initiated democratisation efforts in addition to socioeconomic and security measures. For instance, governments have granted some basic cultural rights to Kurds, such as introducing elective Kurdish courses, legalising sermons, publishing and broadcasting in Kurdish as well as the opportunity to learn the Kurdish language and allowing parents to give their children Kurdish names. In addition, Kurdish political parties are now allowed to conduct party campaigns in Kurdish. The European Union (EU) accession process played a key role in moderating the Turkish state's attitude towards the Kurdish issue (see also Özdemir \& Sarigil 2015).

In addition to accommodating some Kurdish demands as a result of EU pressure, governments have taken some steps towards peacefully resolving the three decades of armed conflict between the security forces and the PKK. The conservative Justice and Development Party (Adalet ve Kalkınma Partisi - AKP) and Kurdish groups (i.e. pro-Kurdish political parties in parliament and the PKK leadership) have been negotiating for a final peaceful settlement of the Kurdish conflict since 2009. Following the failure of the initial attempts (i.e. the 2009 Kurdish Initiative and the 2009-11 Oslo Talks), the government launched direct talks with imprisoned PKK leader Abdullah Öcalan in late 2012, an initiative called the Peace Process (Çözüm Süreci). In March 2013, Öcalan sent a letter from prison on Imrali Island (in the Sea of Marmara) and declared a ceasefire. However, the ceasefire and the Peace Process collapsed after the June 2015 general election and ferocious armed conflict between security forces and the PKK resumed.

Despite the fact that the Kurdish conflict has already resulted in massive human, social and economic costs to both sides, we have not seen mass-scale communal violence between the Turkish majority and the Kurdish minority. Nevertheless, increasing anti-Kurdish attitudes and discourses in society (e.g. see Bora 2003; Saracoglu 2009; Yegen 2009) and the growing number of incidents of sporadic violence in urban settings (e.g. physical attacks against Kurdish seasonal workers and buildings belonging to pro-Kurdish parties and Kurdish businesses in Turkey's western and central Anatolian provinces) further encouraged us to scrutinise the level and determinants of social tolerance between Turks and Kurds.

Given the bloody, prolonged and intractable ethnopolitical conflict in the Turkish setting, it is quite puzzling that the existing literature offers us limited empirical knowledge of the inter-ethnic (in)tolerance between Turks and Kurds. ${ }^{2}$ With such a major limitation in the extant literature, we raise the following questions in this study: How do Kurds and Turks differ in terms of their social tolerance towards out-groups? What factors account for the variance in ethnic (in)tolerance between Turks and Kurds? Are religious individuals more tolerant? Does a cross-cutting sectarian division (i.e. Alevi vs. Sunni) boost inter-ethnic tolerance? How and to what extent do (ethno)nationalist orientations and intergroup contact in the private and public spheres affect ethnic tolerance?

The rest of the article is organised as follows. The next section briefly discusses the nexus between tolerance and democratisation in general. The article then provides a discussion of the existing research on the possible impact of religion (i.e. religiosity and cross-cutting religious sectarian differences), (ethno)nationalism and intergroup social contact on interethnic tolerance and draws some testable hypotheses. The empirical section first presents the variables, measurement and data and then provides statistical results (descriptive and multi-variate analyses). The final section summarises the results of the empirical analyses and discusses the theoretical and practical implications of the findings. 


\section{Tolerance and democracy}

The nexus between political culture and democratic consolidation has been widely discussed in the existing literature. It is argued that institutions (e.g. a liberal constitution, free and competitive elections and political parties) are necessary but not sufficient to make democracy work (Gibson 1998). Democracy also requires a supportive culture, in which ethnic, religious and ideological differences and other salient identities can peacefully coexist. Scholars such as Putnam (1993) note that civic culture is the primary factor that, in his study, generates better democracy and higher economic development in northern Italy. Other scholars also share the argument that consolidating democracy requires not only democratic institutions and procedures but also an appropriate political culture (i.e. democratic values, beliefs and attitudes among the masses) (Almond \&Verba 1989; Diamond 1994a, 1999; Linz \& Stepan 1996; Rose, Mishler \& Haerpfer 1998; Inglehart 2000; Tessler \& Altinoglu 2004).

Values and norms such as tolerance, moderation, civility, respect for opposing viewpoints and willingness to compromise constitute a democratic political culture (e.g. see Diamond 1994a, 1994b; Inglehart 2000). Similarly, Gibson (2006, p. 21), who defines tolerance as 'putting up with that with which one disagrees', suggests that it is 'one of the few viable solutions to the tensions and conflict brought about by multiculturalism and political heterogeneity'. Gibson (2006, p. 29) treats tolerance as an 'essential endorphin of a democratic body politic', stating that '[i]ntolerance not only threatens established democratic systems, but it also makes democratic transitions arduous by undermining the consolidation of democracy (as in so-called illiberal democracies), especially in multicultural polities'.

If tolerance is regarded as one of the cultural requisites of a strong and vibrant democracy, then it is worthwhile to investigate the causal factors and dynamics behind the level of (in) tolerance among ethnic groups, particularly in multi-ethnic societies challenged by severe, prolonged ethno-political conflicts such as Turkey. Investigating ethnic tolerance in such countries is essential because the lack of tolerance, in particular intolerance towards politically salient ethnic groups, can deepen social divisions to the extent that it increases distrust among ethnic groups, which, in return, makes it difficult to overcome major local and national challenges. For example, intolerance poses a major task especially regarding solving ethnic conflict in a country where thousands of people have been killed because of it and billions of dollars spent on security apparatus to combat it. Intolerance begets intolerance, resulting in an unconsolidated democracy and even a reversion to authoritarian regimes if the elites are adept at manipulating historical episodes, prejudices and economic problems for the sake of power (Snyder 2000; Hutchison 2014). A functioning democracy requires the different ideological or ethnic groups to have a substantial level of tolerance towards each other's social, political and economic demands; therefore intolerance has grave social and political ramifications that can lead to devastating outcomes such as ethnic cleansing or separatism (Sekulić, Massey \& Hodson 2006).

\section{Hypotheses}

In this study, we are particularly interested in the three major factors that influence interethnic tolerance: religious identification, (ethno)nationalism and intergroup contact. In this 
section, building upon the existing literature, we offer four testable hypotheses on the impact of these factors on inter-ethnic social tolerance.

\section{Religious identification}

According to studies on the role of shared identity in inter-ethnic relations, one argument, also known as the 'the common in-group identity model', asserts that in-group bias can be reduced when members of different groups perceive themselves as part of a shared, inclusive, overarching category (e.g. a shared religion) (e.g. see Gaertner \& Dovidio 2000). It is expected that a shared, superordinate identity will suppress negative feelings towards out-group members and so foster intergroup harmony. In contrast, in countries where people adhere to different religions, they may be mobilised along religious lines, which stimulates intolerance towards out-group members (Stouffer 1955; Hodson, Sekulic \& Massey 1994). However, this linkage may operate indirectly, for example, through a complex process of group differentiation, as Kunovich and Hodson (1999) find in Croatia, where religion is likely to be a boundary marker as a result of historical factors such as the policies of the former Yugoslavia and the civil war that followed the fall of that regime.

In the Turkish case, Islam cannot be a strong boundary marker because the vast majority of Turks and Kurds self-identify as Muslim. Thus, being Muslim is a religious superordinate identity. One might expect that a strong attachment to a shared, overarching Muslim identity might promote tolerance between ethnic in-group and out-group members. For instance, Hindriks, Verkuyten and Coenders (2014, p. 56) expect that 'when individuals identify more strongly with their religious group, they can be expected to regard those who have the same faith more strongly as in-group members'. Therefore, one can expect that members of ethnic groups with high religiosity are more likely to evaluate one another positively than those with lower religiosity. In their analysis of inter-ethnic minority relations among immigrant groups in the Netherlands, the authors found some empirical support for their expectation: more-religious Muslim respondents were more positive towards the Muslim out-group (i.e. Turkish and Moroccan immigrants).

Such an expectation is also widely shared among conservative circles in Turkey, including AKP officials. Rather than to nationality or ethnicity, these circles attribute greater value and significance to overarching identities such as the 'Islamic brotherhood' or 'ummah' (the worldwide community of Muslim believers) (see also Sakallioglu 1998; Ataman 2003; Akturk 2011; Gurses 2015). Treating Islam as a cement between Turks and Kurds, these circles expect that promoting a shared Muslim identity will weaken the role of ethnicity in self-identification and improve inter-ethnic relations between the two groups. For instance, Yavuz (1998, p. 12) claims that 'the Islamic layer of identity could be useful in terms of containing ethnic tensions and finding a peaceful solution. Therefore, it is expected that promoting Islam and Islamic values in society will enhance inter-ethnic tolerance. Some empirical works, however, provide contrary evidence; that is, they find a negative association between religiosity and tolerance (e.g. see Carkoglu \& Toprak 2007, p. 53; Yesilada \& Noordijk 2010). Given all these factors, we expect:

$\mathrm{H}_{1}$ : Religious Turks and Kurds in Turkey are more likely to show tolerance towards ethnic outgroup members.

In addition to the degree of religiosity, we investigate the possible impact of sectarian differences on inter-ethnic social tolerance. We are particularly interested in the possible 
effect of cross-cutting sectarian cleavages. Regarding cross-cutting versus overlapping cleavages, a classic work asserts that reinforcing or overlapping cleavages are relatively more likely to lead to conflict and contentious politics (see Truman 1951). Another classic work, however, shows that despite a highly segmented society with overlapping cleavages, a stable and effective democracy was achieved in the Netherlands (Lijphart 1968).

In the Turkish context, although the vast majority of Turks and Kurds are Muslim, there are major sectarian divisions within the religion. Most people subscribe to the Sunni Islamic jurisprudence (around 90 per cent of respondents identify themselves as Sunni Muslim). Alevis, known as a heterodox, syncretistic Muslim community, constitute the second-largest religious sect. ${ }^{3}$ The Alevi-Sunni sectarian division cross-cuts the ethnic division (Turks vs. Kurds). For instance, Turkish Alevis share similar norms, values and rituals with Kurdish Alevis. It is expected that the cross-cutting Alevi-Sunni cleavage improves inter-ethnic relations between Turks and Kurds (see Kocher 2002).

Moreover, Alevis were suppressed and persecuted under the Ottoman administration, which officially adopted Sunni (Hanefi) Islamic jurisprudence. As a result, they remained socially, politically and economically marginal and peripheral for centuries (Erdemir 2005). Although the suppression of Alevi identity declined after the establishment of the secular Republic in the early 1920s, Alevis' marginal and peripheral status persisted (Erdemir 2005; Poyraz 2005). For instance, Erdemir (2005, p. 938) notes that before the 1980s, Alevis were defined as one of the three major threats to the Turkish state, together with communism and Kurdish nationalism. Having experienced Ottoman-Turkish discrimination and suppression, Alevis are more likely to have strong empathy towards Kurds, who have endured similar prejudice and discrimination in the social and public realms. Last but not least, Alevis are also regarded as a secular, progressive, tolerant and democratic community (Shankland 2003; Erdemir 2005, p. 939; Poyraz 2005, pp. 503-504). Thus, one might anticipate out-group bias to be limited within Alevi Turks and Kurds in Turkey:

$\mathrm{H}_{2}$ : Alevi Turks and Kurds in Turkey are more likely to show tolerance towards ethnic out-group members.

\section{(Ethno)nationalism}

Social identity theory, which draws attention to the role of self-conception in group membership, group dynamics and processes and in intergroup interactions and relations, asserts that in an intergroup setting, group members seek to differentiate their in-group from out-groups by making comparisons that augment or accentuate similarities within the in-group and differences from out-groups. It is further argued that group members tend to achieve and maintain a positive social identity by assessing in-group members more positively or favourably than out-group members. As Hogg (2007, p. 902) states, 'The group pursuit of positive distinctiveness is reflected in people's desire to have a relatively favourable self-concept, in this case through positive social identity.' A desire for a favourable selfconcept or self-esteem (i.e. positive social identity) encourages individuals to degrade outgroup members relative to in-group members (also known as in-group-favouring bias) (see Tajfel 1981, 1982; Tajfel \& Turner 1986; Hogg 2006).

In the context of inter-ethnic relations, we expect in-group favouritism or ethnocentric orientations to be stronger among those who strongly identify themselves with the ethnic or national group, which decreases tolerance towards out-group members. For example, in 
their studies of the US, Gurin, Hatchett and Jackson (1989) find that black nationalism is associated with intolerance towards whites. In the South African context, Gibson (2006) finds empirical support for a negative relationship between strong group attachment and intolerance. He suggests that those who feel less secure perceive an out-group threat more, which leads to high intolerance. A recent study that examines national identity in the European context suggests that higher in-group projection produces negative out-group attitudes, reducing intergroup social tolerance (Wenzel, Mummendey \& Waldzus 2007).

The prolonged ethnic tension in Turkey provides an important testing ground for assessing the impact of ethnocentric orientations on social tolerance. It is a fact that citizenship in Turkey is founded upon Turkish identity (Yegen 2004). It is likely that Turks regard the nation as reflecting their own ethnic group rather than as an inclusive, shared category (Celebi et al. 2014). Turks who perceive their ethnic group as the founding one are likely to discourage in-group dissent and spurn those who challenge their perception and narratives. We have no reason to believe that Kurds would behave differently towards those who aim to oppose or at least restrict their cultural, political and economic demands. In sum, strong ethnocentric orientations or positive in-group distinctiveness (i.e. the tendency to view the in-group more favourably than an out-group) would be stronger among (ethno)nationalists, and so they would have stronger negative attitudes towards out-group members. Thus, our expectation is that:

$\mathrm{H}_{3}$ : (Ethno)nationalist group members are less likely to show tolerance towards ethnic outgroup members.

\section{Intergroup social contact}

The literature also draws attention to the effect of intergroup social contact on inter-ethnic social tolerance. Several studies in various national settings suggest that intergroup contact limits prejudice towards out-group members and limits hostility among groups. Thus, it is suggested that regular intergroup contact is likely to boost harmony and mutual understanding in society and so improve ethnic relations (e.g. see Allport 1954; Voci \& Hewstone 2003; Dovidio, Gaertner \& Kawakami 2003; McLaren 2003; Pettigrew 1997, 1998; Wagner et al. 2003; 2006; Brown et al. 2007; Pettigrew \& Tropp 2006, 2008; Ward \& Masgoret 2006; Dixon et al. 2010; Frølund Thomsen 2012; Hindriks, Verkuyten \& Coenders 2014). In the Scandinavian context, for instance, Frølund Thomsen $(2012$, p. 173) concludes that 'intergroup contact makes citizens more tolerant because enduring contact situations promote familiarity through individuating information. Intergroup contact also breeds ethnic tolerance through the weakening of perceived threat - although this effect is less strong.' In the Dutch setting, Hindriks, Verkuyten and Coenders (2014) find that increased contact with members of a particular minority group decreases social distance and bias toward that group.

Allport (1954) emphasises that communication involving deep and intense interaction, such as discussing personal matters and political issues (rather than superficial communication), exerts a strong, positive influence on tolerance. Communication that can produce social tolerance is more likely within families with diverse ethnic members. Therefore, we expect that individuals who have a spouse of another ethnic background or whose parents come from different ethnic groups are likely to be more tolerant. Even if one prefers one ethnic group over another, discussing private matters and political developments in a 
family leads their members to support an out-group's rights or to understand the concerns of the dominant group (e.g. Hayes \& Dowds 2006; Dixon et al. 2010; Pettigrew 1997; Pettigrew \&Tropp 2011; Popan et al. 2010). It is also suggested that ethnic intermarriage might weaken ethnic identifications and so contribute to positive inter-ethnic relations. For instance, Lieberson and Waters suggest that 'intermarriage functions to create more ethnic heterogeneity in their social networks and may possibly lead to a diminution or dilution of ethnic identity' (1988, p. 162). Thus, we expect that:

$\mathrm{H}_{4}$ : Individuals having personal contact with out-group members are more likely to show tolerance towards ethnic out-group.

\section{Variables, measurement and data}

Dependent variable. In this study, we investigate the determinants of social (in)tolerance among Turks and Kurds. Thus, the dependent variable in this study is inter-ethnic social tolerance, which is difficult to measure precisely. Some existing empirical analyses, based on survey data, measure it by asking direct questions of the respondents. For instance, interviewees are expected to respond to questions such as '[The opposite ethnic group is] untrustworthy,' [The opposite ethnic group is] selfish,' [The opposite ethnic group makes] me uncomfortable.'It would be better if [the opposite ethnic group left] our country' (e.g. see Gibson 2006).

We, however, think that asking such direct questions about out-group members may amplify social desirability bias and so enhance measurement error. Therefore, we included relatively more indirect questions in the questionnaire, with responses given as ' 1 ' (yes) or ' 2 ' (no): 'Would you be disturbed or bothered by a neighbour having [the opposite ethnic group] origin?' 'If your child gets married, would you accept a [the opposite ethnic group] son/daughter-in-law?' Imagine that you will set up a business firm and you need to find a partner. Would you work with a [the opposite ethnic group] business partner?' and 'Imagine that you have an apartment. Would you rent it to a [the opposite ethnic group] tenant?' (see also Dunn \& Singh 2014; Hindriks, Verkuyten \& Coenders 2014).

To see whether these items are related to any unobserved latent variable, we conducted principal component analysis, presented in Table 1. The results show that three of these variables (i.e. son/daughter-in-law, business partner, renter/tenant) have relatively higher loadings on a single dimension or factor, which we call'social tolerance.'By using these items, we constructed an additive index of social tolerance for each ethnic group, which ranges from 0 to 3.

Independent variables. Religiosity is one of our main independent variables. Several existing empirical works in the Turkish context suggest that religiosity should be treated as a complex, multidimensional concept, involving several aspects such as belief, attitude and practice (e.g. Carkoglu 2005; Carkoglu \& Kalaycioglu 2009; Yesilada \& Noordijk 2010). To capture its various dimensions, we conducted principal component analysis by using survey items related to religion (e.g. belief in an afterlife and God, daily praying, fasting and support for Sharia law). Our analyses generated two additive indices, capturing two different dimensions of religiosity: faith vs. attitudinal-practical. For a robustness check, we also utilised 'self-reported degree of religiosity' as an alternative indicator, but it did not change the multi-variate regression results. Regarding religious sect, we used self-reports to determine respondents' sectarian affiliation. ${ }^{4}$ 
Table 1. Factor analysis (tolerance).

\begin{tabular}{lcc}
\hline & Turks & Kurds \\
\cline { 2 - 3 } Variables & Factor loadings & Factor loadings \\
\cline { 2 - 3 } & 1 = social tolerance & 1 = social tolerance \\
\hline Son/daughter-in-law & 0.836 & 0.804 \\
Business partner & 0.9 & 0.909 \\
Renter/tenant & 0.88 & 0.892 \\
Neighbour & 0.612 & 0.337 \\
Variance (\%) & 66 & 59 \\
\hline
\end{tabular}

Notes: Extraction method: principal component analysis. Only one component was extracted (no rotation). Emboldened values mark relatively higher factor loadings.

It is also a challenging task to measure (ethno)nationalism, another main independent variable. We believe that support for (ethno)nationalist parties can be used as an indicator of nationalist orientations among in-group members. Thus, we used Turkish support for the ultranationalist, right-oriented Nationalist Action Party (Milliyetçi Hareket Partisi - MHP) and Kurdish support for the pro-Kurdish Peace and Democracy Party (Barış ve Demokrasi Partisi - BDP) as a proxy for ethnic nationalism. ${ }^{5}$ To check our results, we also used an alternative measure: self-reported nationalist orientation, which generated quite similar results.

Concerning social contact, we are interested in the possible impact of intergroup social contact in both the private and public spheres. Regarding contact in the private sphere, we used whether the respondent has a parent (either father or mother) or partner (i.e. fiancé/ fiancée or spouse) from an out-group. With respect to measuring social contact in the public sphere, the literature provides several measures. Some studies use'self-reported workplace contact' (e.g. Frølund Thomsen 2012) while others use 'friendship' as an indicator of public social contact (e.g. Dixon et al. 2010). In this research, due to lack of a direct indicator, we use 'region' as a proxy to measure contact in the public sphere. If the contact hypothesis is correct, then regional factors should also matter. We expect that daily interactions between in-group and out-group members will be relatively limited in ethnically homogeneous regions. Thus, we anticipate that a Kurdish individual in the southeast, where most Kurds in Turkey live, will have fewer opportunities for social contact with Turks in the public sphere. Similarly, a Turk from other regions will have relatively fewer chances to interact with a Kurd. Thus, we created a dummy variable to capture the impact of regional differences on ethnic tolerance: 0 = other regions; 1 = the southeast.

Control variables. The determinants of inter-ethnic tolerance are not limited to our main independent variables. The literature also offers other factors that may have some impact (positive or negative) on inter-ethnic tolerance. In the Turkish model, we control for threat perception, which is regarded as one of the most important predictors of intolerance (see Mclaren 2003; Gibson 2006; Dunn \& Singh 2014). One might expect that Turks who believe that official recognition of Kurdish ethnic identity and granting further cultural and/or political rights to Kurds would result in the disintegration of the country would react negatively to members of the Kurdish ethnic group. To put it differently, perceived threat (e.g. fear of disintegration) among in-group members might generate a negative attitude or even hostility towards members of an ethnic out-group, which, in return, reduces tolerance (see also Mclntosh et al. 1995; Frølund Thomsen 2012). We measure perceived threat by using responses to the following survey item: 'Do you think that if the Turkish state grants a 
kind of "regional autonomy" or "federation" to Kurds, that would lead to the disintegration of the country?'This measure ranged from 1 (yes) to 0 (no).

In the Kurdish model, we control for the possible impact of 'perceived injustice'. Schmitt and Branscombe (2002) show a positive relationship between perceptions of discrimination and in-group identification, which in turn is expected to stimulate prejudice towards the dominant ethnic out-group. This variable involves two separate dimensions: political and socioeconomic. We predict that Kurds who have a perception of discrimination from the Turkish state will be less tolerant towards Turks simply because Kurds who think that the state violates their rights and freedoms are more likely to develop a negative attitude vis-àvis the Turkish out-group. In addition, the economic disparities that Kurds have long experienced may have led to a heightened awareness of their politicised ethnic identity. Kurds may easily establish a direct linkage between their poverty and ethnic identity, and blame the Turkish state and its founding ethnic group, Turks, who are mostly supportive of state policies that produce economic disparity between these two ethnic groups (Icduygu, Romano \& Sirkeci 1999, p. 998).

To measure perceived injustice, we utilised the responses to the following questions: 'In your opinion, do you think the Turkish state discriminates against Kurds in Turkey?' and 'In your opinion, do you think Kurds in Turkey enjoy similar political and cultural rights and freedoms as Turks?'Similarly, we expect that Kurds who think that they are socioeconomically disadvantaged vis-à-vis Turks will be less tolerant towards Turks. Similarly to Dixon et al. (2010), we measure socioeconomic injustice by using perceptions of socioeconomic inequity. We employed the following survey item:'In your opinion, do Kurds in Turkey have social and economic equality with Turks?' Using these three survey items, we constructed an additive index of 'perceived injustice' for the Kurdish subsample. We also included gender, age, income, education, ideology (left-right), the size of residential area and economic satisfaction as common control variables in both models.

Data. To test the above hypotheses about inter-ethnic social tolerance in the Turkish setting, we utilise original and comprehensive public-opinion survey data. As part of a larger research project on the Kurdish issue in Turkey, ${ }^{6}$ we conducted a comprehensive publicopinion survey in early April 2013. ${ }^{7}$ One of the authors took part in the research team that designed the survey, which was administered by $A \& G$, a professional public-opinion research company based in Istanbul. Before implementing the survey, we conducted and participated in pilots in Istanbul, Ankara, Malatya, Mersin and Diyarbakir. After the pilots, we invited all regional heads of $A \& G$ to Ankara to attend a half-day workshop to familiarise them with the research project and the questionnaire. The pilots showed that Kurdish participants appeared more comfortable and responsive when they were interviewed by a Kurdish-speaking female interviewer. Thus, in order to limit social desirability bias, we used trained and experienced female Kurdish interviewers from A\&G in regions dominated by Kurds. The final survey involved face-to-face interviews with 7,103 participants from seven regions, 50 provinces and 398 districts and villages. Regarding sampling, respondents were selected using a multistage, stratified, cluster-sampling procedure. Age and gender quotas were also applied.

The statistical analyses below were conducted with data provided by the Turkish and Kurdish sub-samples. There are multiple ways of identifying respondents' ethnic origins. A common strategy is to use 'mother language' as an indicator. Another strategy is to rely on respondents' reports of their ethnic origin or identity. For a robustness check, we utilised both and our descriptive analyses using these two different indicators produced similar 


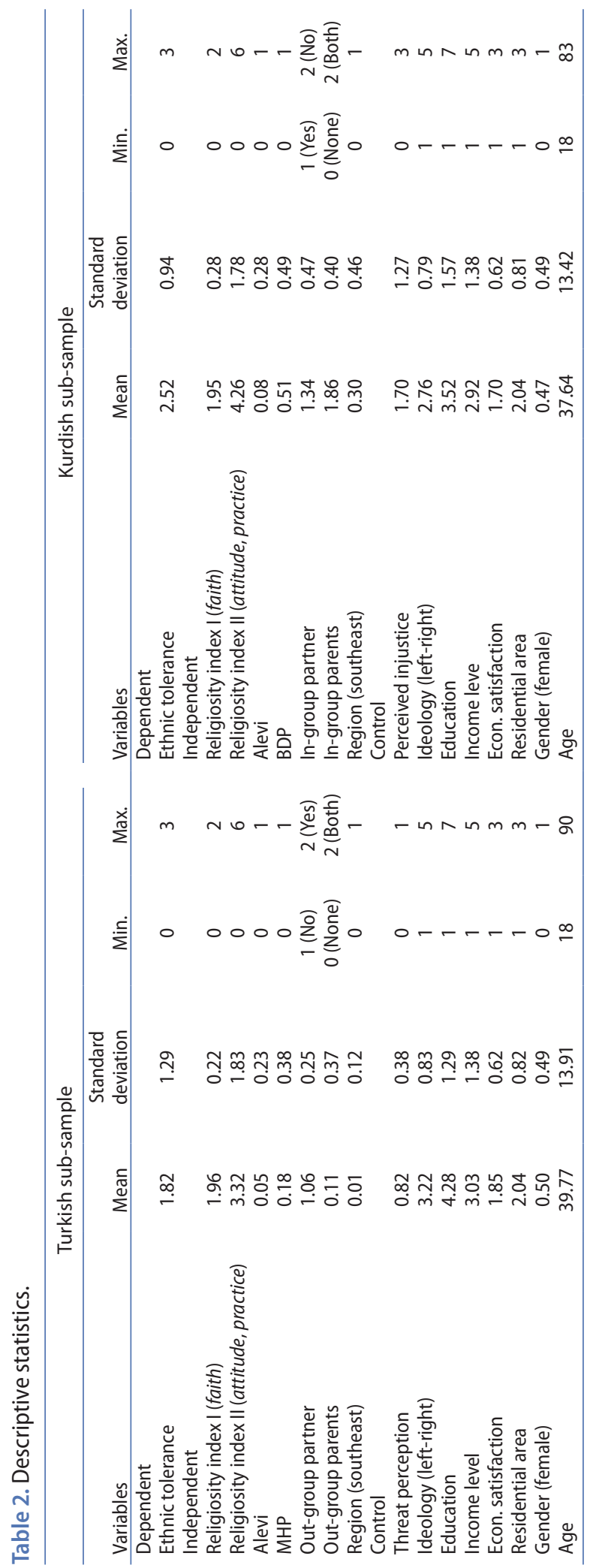




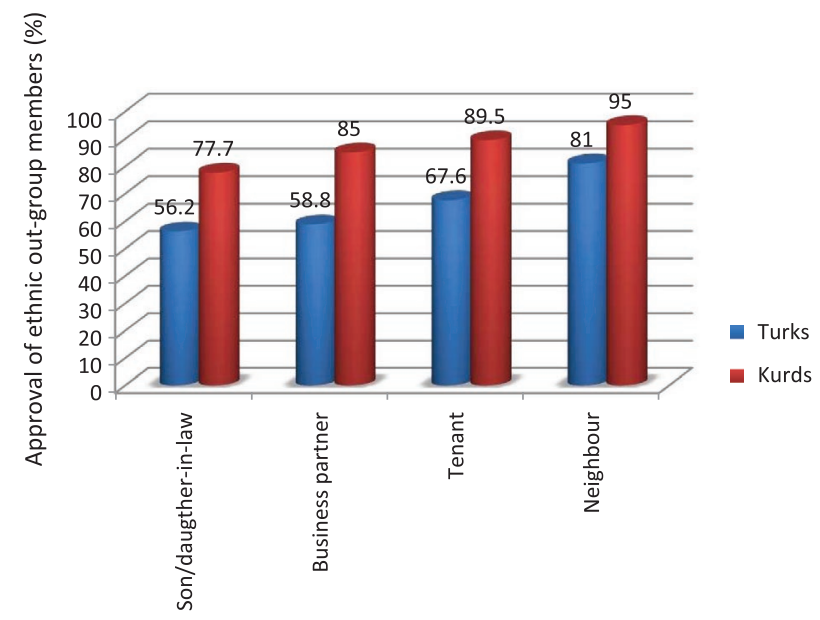

Figure 1. Turkish and Kurdish attitudes towards each other (April 2013).

results. Thus, we only present the results based on participants' self-definition as an indicator of ethnic origin. Accordingly, 76.3 per cent of respondents identify themselves as ethnic Turks; and 17.5 per cent declare themselves to be Kurdish. Table 2 presents the descriptive statistics for all the variables.

\section{Empirical results}

Descriptive findings. Beginning with the descriptive analyses, the results confirm that the level of social tolerance varies across the two groups. Figure 1 suggests that ethnic tolerance is much lower among Turks than among Kurds. As indicators of ethnic tolerance, we use support for or a positive attitude towards having a son/daughter-in-law, business partner, tenant or neighbour from an ethnic out-group. As Figure 1 indicates, average support level is much lower among Turks (65.9 per cent vs. 86.8 per cent among Kurds). Interestingly, however, in both groups, support for having a son/daughter-in-law from another ethnic group is the lowest (56.2 per cent and 77.7 per cent) and support for a neighbour from another ethnic group is the highest ( 81 per cent and 95 per cent). This distribution suggests that both Turks and Kurds are relatively less tolerant towards the idea of having a family member from an ethnic out-group, which can be interpreted as evidence of a certain degree of exclusionary attitude towards one another. However, this exclusionary attitude is stronger among Turks.

How can we explain such a gap between Turks and Kurds? Is it an anomaly or an expected pattern? Our descriptive finding appears to be consistent with identity theory, which holds that more-powerful and dominant groups tend to espouse stronger prejudices towards minority groups under conditions of prolonged, intractable conflict (Tajfel \& Turner 1979; Dixon \& Ergin 2010). Gibson and Gouws (2003) argue that in deeply fractionalised societies, group identities lead their members to take on an 'us' versus 'them' mentality towards nonconformist groups. Thus, ethnic Turks, who tend to align themselves with the Turkish state and hold stronger national identification with it, are more likely to develop negative attitudes towards Kurds, who generally do not conform to the state and its national identity 
Table 3. Ordinal logit analysis of inter-ethnic tolerance (Turks and Kurds).

\begin{tabular}{|c|c|c|}
\hline \multirow[b]{2}{*}{ Predictors } & \multicolumn{2}{|c|}{ Dependent variable: 'ethnic tolerance towards out-group' } \\
\hline & Turkish model & Kurdish model \\
\hline \multicolumn{3}{|l|}{ Religiosity/sectarian identity } \\
\hline Religiosity (faith) & $0.0696265(0.1696837)$ & $0.2874144(0.2633693)$ \\
\hline Religiosity (attitude, practice) & $0.1012953(0.0193321)^{* * *}$ & $0.0742976(0.0508734)$ \\
\hline Alevi & $0.0810806(0.1241577)$ & $0.3159018(0.2693229)$ \\
\hline \multicolumn{3}{|l|}{ (Ethno)nationalism } \\
\hline $\begin{array}{l}\text { MHP } \\
\text { BDP }\end{array}$ & $-0.5208718(0.0781447)^{* * *}$ & $-1.045761(0.1832339)^{* * *}$ \\
\hline \multicolumn{3}{|l|}{ Intergroup social contact } \\
\hline $\begin{array}{l}\text { Out-group partner } \\
\text { In-group partner }\end{array}$ & $0.8729331(0.1514528)^{* * *}$ & $0.1326767(0.1930256)$ \\
\hline $\begin{array}{l}\text { Out-group parents } \\
\text { In-group parents }\end{array}$ & $0.8998031(0.1165062)^{* * *}$ & $0.1696034(0.2270048)$ \\
\hline Southeast & $0.6538013(0.2226038)^{* *}$ & $0.2529792(0.2017958)$ \\
\hline \multicolumn{3}{|l|}{ Control variables } \\
\hline $\begin{array}{l}\text { Threat perception } \\
\text { Perceived injustice }\end{array}$ & $-0.2100297(0.0797598)^{* *}$ & $-0.0218767(0.0686315)$ \\
\hline Ideology & $-0.0845029(0.0415673)^{*}$ & $0.2,419,296(0.1139217)^{*}$ \\
\hline Education & $0.0487257(0.0283994)$ & $0.0965009(0.0681929)$ \\
\hline Income & $0.0677271(0.0249234)^{* *}$ & $0.0938981(0.0723891)$ \\
\hline Economic satisfaction & $0.1,185,763(0.0509644)^{*}$ & $0.1,627,123(0.1357135)$ \\
\hline The size of residential area & $0.0977123(0.0362201)^{* *}$ & $0.0831439(0.0868834)$ \\
\hline Gender & $0.0033161(0.0590438)$ & $-0.1433817(0.1562424)$ \\
\hline Age & $0.0038143(0.0022893)$ & $0.0035524(0.0071556)$ \\
\hline$\tau_{1}$ & $0.9194295(0.4382203)$ & $0.1765734(1.005984)$ \\
\hline$\tau_{2}$ & 1.47959 (0.4387638) & $0.630008(1.009021)$ \\
\hline$\tau_{3}^{2}$ & $2.007436(0.4390135)$ & 1.499589 (1.018492) \\
\hline$N^{3}$ & 4,345 & 1,046 \\
\hline Pseudo $R^{2}$ & 0.0327 & 0.0469 \\
\hline Log pse. likelihood & -5105.3223 & -829.33988 \\
\hline Wald $X^{2}(15)$ & 261.88 & 73.12 \\
\hline Prob $>x^{2}$ & 0.0000 & 0.0000 \\
\hline
\end{tabular}

Notes: The values in parentheses are robust standard errors. ${ }^{*} p<0.05 ;{ }^{* *} p<0.01$; ${ }^{* * *} p<0.001$.

based on Turkishness. Alternatively, one might postulate that the outcome is due to the fact that Kurds have more out-group contacts, which diminishes their prejudice towards Turks (Tam et al. 2009). Last, we might suggest that the difference is due to asymmetric distribution of information across the groups. Since Kurds constitute a minority in a country dominated by Turks, they will have more information on the ethnic majority.

Multi-variate statistical analyses. In order to analyse the determining factors of inter-ethnic social tolerance and test the hypotheses presented above, we conducted multi-variate regression analyses. Since our dependent variable ranged from 0 to 3, with four categories, we ran ordinal logistic regression due to the nature of the categories and for theoretical reasons (see also Dow \& Endersby 2004).

Table 3 presents the results of the ordinal logit analyses of inter-ethnic tolerance between Turks and Kurds. For the Turkish model, the results suggest that the faith dimension of religiosity does not matter. However, the attitudinal/practical dimension of religiosity seems to increase the likelihood of tolerance towards Kurds. Thus, the religiosity hypothesis is partially supported by the Turkish model. Regarding sectarian identification, we see that being Alevi does not exert any statistically significant effect on tolerance. This finding disproves our hypothesis about the impact of crosscutting cleavages on social tolerance. 
One of the most robust and consistent findings is related to the impact of nationalist orientation: voting for the ultranationalist party (i.e. the MHP) is associated with a low level of tolerance towards Kurds, proving the hypothesis about the impact of ethnonationalist orientations (see also Carkoglu \& Toprak 2007, p. 53). Concerning the contact hypothesis, we see that having private contacts with out-group members (i.e. having a Kurdish parent and/or a Kurdish partner) increases the likelihood of Turks' social tolerance towards Kurds. ${ }^{8}$ The public contact variable, operationalised as residing in the Kurdish southeast, also increases Turkish tolerance towards Kurds. These results suggest that more interactions with Kurds as a result of living in the region and more intimate contacts as a result of having a Kurdish family member are likely to contribute to Turks' tolerance towards Kurds.

With respect to control variables in the Turkish model, threat perception appears to reduce Turks' tolerance towards Kurds. In other words, Turks who think that granting further rights to the Kurdish out-group would result in the disintegration of the country are less likely to have a positive attitude vis-à-vis Kurds. Similarly, moving from the left of the ideological spectrum to the right also decreases tolerance towards Kurds. This result suggests that leftoriented Turkish individuals are more likely to show tolerance towards Kurds (see also Carkoglu \& Toprak 2007, p. 53; Yesilada \& Noordijk 2010, p. 22). Economic factors such as income level and economic satisfaction also seem to enhance tolerance towards Kurds. Finally, Turks living in urban centres are relatively more likely to have a positive attitude visà-vis Kurds (see also Carkoglu \& Toprak 2007, p. 51). This finding can also be interpreted as an indicator of the positive role of social contact with Kurds in urban settings.

Moving to the Kurdish model, we find that, contrary to the Turkish model, neither the belief nor the practice dimension of religiosity has any statistically significant effect on social tolerance among Kurds. In other words, the Kurdish model disproves the religiosity hypothesis. As in the Turkish model, however, in terms of sectarian differences, Alevis (Kurds) are not distinguishable in terms of the tolerance they exhibit towards out-group members. Ethnocentric orientations seem to operate similarly within the Kurdish group. Kurds who vote for an ethnonationalist political party are less likely to show tolerance towards Turks. In other words, the Kurdish model also confirms the hypothesis, which expects a negative impact of ethnonationalist orientations on social tolerance. As for the contact variables, none of them (i.e. having a partner and/or a parent from ethnic out-groups or living in Kurdish-dominant areas) exerts any significant effect on Kurds' tolerance towards Turks, disconfirming the contact hypothesis.

In terms of the control variables in the Kurdish model, contrary to our expectations, the perception of injustice does not reduce the likelihood of tolerance towards Turks. To put it differently, Kurds with a perception of injustice are not less likely to be tolerant towards members of the dominant Turkish out-group. This result is probably because Kurds attribute the source of injustice to state policies and actions rather than to specific members of Turkish society (see also Gurses 2010; Karakoc 2013). In contrast to the Turkish model, left-oriented Kurds are less likely to show tolerance towards Turks. To put it differently, compared with left-oriented Kurds, right-oriented Kurds are more likely to show tolerance towards members of the Turkish ethnic out-group. Hence, ideology operates quite differently across these two ethnic groups. This finding suggests that the likelihood of conflict or tension is greater among right-oriented Turks and left-oriented Kurds. Also contrary to the Turkish model, economic factors (i.e. income and economic satisfaction) do not have any statistically significant impact on Kurdish tolerance. And in both models, education fails to have any impact. These results 
suggest that improvements in Kurds' socioeconomic status would not necessarily improve Kurdish tolerance towards Turks.

\section{Conclusions and implications}

Overall, our empirical analyses of inter-ethnic tolerance show that different factors and dynamics shape the level of tolerance within ethnic majority and minority groups in the Turkish setting. Such an outcome should not be surprising because the experiences and expectations of these two groups have been quite different. Kurdish ethnic identity was denied and suppressed by the Turkish state until the early 2000s (Yegen 2009). On the other hand, Turkish identity, which constituted the foundation of the Republican nation state, has been promoted as the dominant, overarching category by the state through many channels, such as national education. The Turkish case, thus, suggests that when we study inter-ethnic tolerance we should also take into account the implications of differences in group status.

Our findings partly support the literature that takes religiosity as a superordinate identity and expects it to increase social tolerance. As our statistical results indicate, religiosity seems to boost social tolerance towards Kurds within the Turkish ethnic group. However, the religiosity hypothesis does not work in the case of the Kurdish group. In other words, the attitudinal and practical dimensions of religiosity exert a significant positive impact on social tolerance only within the dominant ethnic group - Turks.

In light of this finding, it is interesting to observe that several conservative circles in Turkey treat Islam as a 'shared value', 'a unifying bond' or a 'bridge' between Turks and Kurds, and expect that promoting Islamic ideas and values within the Kurdish ethnic minority will curb Kurdish ethnonationalism and improve inter-ethnic relations. Our findings show that such an assumption is problematic. Islam can be a shared value but Islamic identity does not necessarily constitute an antidote to Kurdish ethnonationalism or intolerance. Thus, the discourse of 'Islamic brotherhood' may sell well among religious Turks and even ensure a certain degree of support for the conservative AKP government's recent efforts to find a peaceful settlement to the Kurdish problem (see also Akturk 2011), but such a discourse may not have the desired effect among Kurds (see also Sarigil \& Fazlioglu 2014; Gurses 2015). A recent ethnographic study shows that Kurdish ethnonationalists are highly critical of such discourse, considering such ideas assimilationist (see Sarigil \& Fazlioglu 2013).

Sectarian identity (i.e. being Alevi) does not really boost social tolerance among Turks or Kurds. This finding questions the argument that the cross-cutting Alevi-Sunni cleavage improves inter-ethnic relations between Turks and Kurds in the Turkish setting. (Ethno) nationalist attachments and tendencies appear to have a consistent negative impact on social tolerance in both models. Put differently, nationalist Turks and Kurds are both less likely to be tolerant towards ethnic out-group members. This finding suggests that accentuating Turkish and Kurdish nationalisms is likely to prevent constructive dialogue, undermining the social and political order in Turkey (see also Özkırımlı 2014).

Regarding the role of social contact, the Turkish model provides evidence confirming the contact hypothesis. Private contact (having a partner and parent from the out-group) enhances tolerance towards out-group members among Turks. In addition, Turks living in the southeast (mostly inhabited by Kurds) are more likely to interact with Kurds. As a result, we see that Turks in that region show more social tolerance towards Kurds. The Kurdish 
model, however, does not provide any supporting evidence for the contact hypothesis. Having personal contact with out-group members in either the private or public sphere does not affect Kurds' social tolerance. One practical implication of these findings is that increasing contact between Turks and Kurds has the potential to improve inter-ethnic relations in the Turkish context. It would at least facilitate the evolution of a positive attitude towards the ethnic minority (i.e. Kurds) among the ethnic majority (i.e. Turks).

Concerning other notable findings, higher perceptions of threat (e.g. fear of disintegration) seem to reduce Turks' tolerance towards Kurds. Policies aimed at changing such perceptions would certainly contribute to improved inter-ethnic relations between the two groups. In addition, improvements in economic well-being would also facilitate the evolution of more positive attitudes among Turks towards Kurds. However, socioeconomic variables fail to explain Kurds' attitudes towards Turks. This finding implies that socioeconomic measures would not necessarily alter Kurdish attitudes.

Considering all of the above, empirical analyses of inter-ethnic tolerance in Turkish context show that the social setting in Turkey appears to be not so favourable for democratic consolidation. In other words, in terms of the social requisites of democracy (e.g. tolerance), there are still major hurdles in front of Turkish democratic development. Although the official state discourse presents Turks and Kurds as inseparable units, coexisting peacefully, the empirical findings of this study show that inter-ethnic relations between Turks and Kurds are not without tensions or difficulties. It appears that the ongoing Kurdish conflict in Turkey has promoted inter-ethnic tensions. As one manifestation of such tensions, we see an increasing number of clashes between Turkish and Kurdish mass groups in urban centres. Limited inter-ethnic social and political tolerance and the resultant inter-ethnic tensions and clashes not only threaten political stability in the country but also retard the democratisation process.

We believe that the empirical findings of this study contribute to the several existing debates in the fields of inter-ethnic relations and tolerance and democratisation. In particular, while most studies in the ethnic tolerance literature have investigated attitudes towards minority groups, they have ignored how minority groups develop attitudes towards majority groups (Doosje, Ellemers \& Spears 1995). We aim to shed light on this understudied relationship between members of an ethnic minority and majority in the Turkish setting, where there is a limited number of studies on social tolerance between Kurds and Turks. Second, our finding on religiosity challenges the dominant view: we discovered that, contrary to the dominant understanding, strong religious identification results in strong tolerance towards Kurds among Turks, but not towards Turks among Kurds. Third, to our knowledge, this is the first study that tests the impact of a salient sectarian identity on tolerance, and it finds that belonging to a cross-cutting sectarian identity (i.e. being Alevi) does not necessarily increase tolerance towards ethnic out-group members. Fourth, the findings mark the difficulties of the democratisation process in the Turkish setting. Although the Turkish state has taken several steps to accommodate some Kurdish demands since the early 2000s, public Turkish intolerance towards the Kurdish minority is still high. This fact suggests that the moderation of the state's attitude towards the Kurdish problem and the state's efforts to enhance Kurdish minority rights are not necessarily improving interethnic relations and attitudes. Instead, we see still strong Turkish intolerance towards Kurds and Kurdish rights. 


\section{Notes}

1. There are also studies arguing that Kurds in Turkey comprise higher percentages of the total population such as 20 per cent (e.g. see Romano \& Gurses 2014, p. 11) or 20-28 per cent (Gunes 2012, p. 1).

2. For a few exceptions, see e.g. Dixon \& Ergin 2010; Çelebi et al. 2014.

3. Due to social, economic and political marginalisation, Alevis have been reluctant to reveal their identity, making it difficult to know precisely how many Alevis live in Turkey. The size of the Alevi community is estimated to be around 10-20 per cent of the population (e.g. see Carkoglu 2005; Erman \& Göker 2000; Erdemir 2005; Poyraz 2005). Our survey findings show that six per cent of respondents declare themselves to be Alevi; however,'no response' answers are particularly high for this survey item (six per cent) and we suspect that most of these are from respondents of Alevi origin. Thus, we can estimate that the Alevi population corresponds to at least ten per cent of Turkish society. Using a more indirect set of survey items, Carkoglu (2005) estimates the size of the Alevi population to be around 15 per cent.

4. Due to lack of a better measure, we rely on respondents' self-reports; however, we recognize the possibility of social desirability bias with the survey items that directly ask the respondents which religious sect they belong to (see also note 7). Nevertheless, this survey item will at least allow us to see if strong Alevi identification has any impact on inter-ethnic tolerance.

5. Our descriptive analyses show that among Kurds, BDP voters are more likely to have ethnonationalist orientations (e.g. support for Kurdish independence). Thus, support for the BDP becomes a useful proxy for ethnonationalist orientations among Kurds. The BDP, which represented the Kurdish movement in party politics at the time of the survey, was replaced by People's Democracy Party (Halkların Demokrasi Partisi - HDP) in 2014.

6. The data that this study utilises come from a broader research project fully funded by the TEPAV (Türkiye Ekonomi Politikaları Araştırma Vakfı - Economic Policy Research Foundation of Turkey). The first author of this article took part as one of the leading researchers in that research project. The primary motivation of that research was to understand and explain Kurdish demands and Turkish reactions to those demands. Another goal was to analyse inter-ethnic relations between Turks and Kurds in the Turkish setting.

7. Thus, the survey was conducted during a relatively peaceful social and political environment (i.e. in the aftermath of PKK leader Öcalan's letter calling for a ceasefire in March 2013). If we repeated the same survey under the conditions of armed conflict and bloodshed which resumed in summer 2015, we would likely get a higher degree of social distance between Turks and Kurds simply because during armed conflict, the ethnic majority group's prejudice and exclusionary attitude towards the ethnic minority is likely to be exacerbated (see also Tajfel \& Turner 1979; Dixon \& Ergin 2010; Hutchison 2014).

8. We should, however, acknowledge the possibility of the endogeneity problem with the 'partner' variable (having a partner, wife or husband from an ethnic out-group) because marrying someone from an ethnic out-group may be due to having high tolerance for out-group members. However, endogeneity is not really an issue with the 'parent' variable, which has a positive and significant impact on ethnic tolerance.

\section{Acknowledgments}

Earlier versions of this article were presented at the 72nd Annual National Conference of the Midwest Political Science Association (MPSA), 3-6 April 2014, Chicago, and at the 2014 World Convention of the Association for the Study of Nationalities (ASN), 24-26 April 2014, New York. For useful comments on earlier drafts of this study, we are grateful to Sener Akturk, Yasin Bostanci, Hamit Bozarslan, Esra Cuhadar, Gunes Ertan, Richard Jankowski, Carolyn Morgan, the Editors of South European Society and Politics and two anonymous reviewers. 


\section{Disclosure statement}

No potential conflict of interest was reported by the authors.

\section{Funding}

The data that this study utilises derive from a broader research project funded by the TEPAV.

\section{Notes on contributors}

Zeki Sarigil is an associate professor of political science at Bilkent University (Ankara). He received his PhD from the University of Pittsburgh in 2007. His research interests include ethnonationalism, civil-military relations, institutional theory and Turkish politics. He has published articles in journals such as European Political Science Review, European Journal of International Relations, Armed Forces \& Society, Nations and Nationalism, Ethnic and Racial Studies, Critical Policy Studies, Mediterranean Politics and Turkish Studies.

Ekrem Karakoc is an assistant professor in the Department of Political Science at Binghamton University - State University of New York. He received his PhD from Pennsylvania State University in 2010. His dissertation received the 2011 Juan Linz Prize for Best Dissertation, awarded by the American Political Science Association's Comparative Democratisation Section. His field is comparative politics with a focus on comparative political economy, democratisation and political behavior. His work has appeared in World Politics, Comparative Politics, Comparative Political Studies, Electoral Studies, European Political Science Review, Canadian Journal of Political Science, International Journal of Comparative Sociology and Turkish Studies.

\section{References}

Aktürk, Ş. (2011)'Regimes of ethnicity: comparative analysis of Germany, the Soviet Union/post-Soviet Russia, and Turkey', World Politics, vol. 63, no. 1, pp. 115-164.

Allport, G. W. (1954) The Nature of Prejudice, Addison-Wesley Pub. Co., Cambridge, MA.

Almond, G. A. \& Verba, S. (1989) The Civic Culture: Political Attitudes and Democracy in Five Nations, Sage Publications, Thousand Oaks, CA.

Ataman, M. (2003) 'Islamic perspective on ethnicity and nationalism: diversity or uniformity?' Journal of Muslim Minority Affairs, vol. 23, no. 1, pp. 89-102.

Aydin, A. \& Emrence, C. (2015) Zones of Rebellion: Kurdish Insurgents and the Turkish State, Cornell University Press, Ithaca, NY.

Bora, T. (2003) 'Nationalist discourses in Turkey', South Atlantic Quarterly, vol. 102, no. 2-3, pp. 433-451.

Brown, R., Eller, A., Leeds, S. \& Stace, K. (2007)'Intergroup contact and intergroup attitudes: a longitudinal study', European Journal of Social Psychology, vol. 37, no. 4, pp. 692-703.

Çarkoğlu, A. (2005) 'Political preferences of the Turkish electorate: reflections of an Alevi-Sunni Cleavage', Turkish Studies, vol. 6, no. 2, pp. 273-292.

Carkoglu, A. \& Kalaycioglu, E. (2009) Rising Tide of Conservatism in Turkey, Palgrave Macmillan, New York, NY.

Çarkoğlu, A. \& Toprak, B. (2007) Religion, Society and Politics in a Changing Turkey, TESEV, Istanbul.

Çelebi, E., Verkuyten, M., Köse, T. \& Maliepaard, M. (2014) 'Out-group trust and conflict understandings: the perspective of Turks and Kurds in Turkey', International Journal of Intercultural Relations, vol. 40, pp. 64-75.

Diamond, L. (1994a) Political Culture and Democracy in Developing Countries, Lynne Rienner Publishers, Colorado, CO.

Diamond, L. (1994b) ‘Toward democratic consolidation', Journal of Democracy, vol. 5, no. 3, pp. 4-17.

Diamond, L. (1999) Developing Democracy: Toward Consolidation, JHU Press, Maryland. 
Dixon, J., Durrheim, K., Tredoux, C. G., Tropp, L. R., Clack, B., Eaton, L. \& Quayle, M. (2010) 'Challenging the stubborn core of opposition to equality: racial contact and policy attitudes', Political Psychology, vol. 31, no. 6, pp. 831-855.

Dixon, J. C. \& Ergin, M. (2010) 'Explaining anti-Kurdish beliefs in Turkey: group competition, identity, and globalisation', Social Science Quarterly, vol. 91, no. 5, pp. 1329-1348.

Doosje, B., Ellemers, N. \& Spears, R. (1995)'Perceived intragroup variability as a function of group status and identification', Journal of Experimental Social Psychology, vol. 31, no. 5, pp. 410-436.

Dovidio, J. F., Gaertner, S. L. \& Kawakami, K. (2003) 'Intergroup contact: the past, present, and the future', Group Processes \& Intergroup Relations, vol. 6, no. 1, pp. 5-21.

Dow, J. K. \& Endersby, J. W. (2004) 'Multinomial probit and multinomial logit: a comparison of choice models for voting research', Electoral Studies, vol. 23, no. 1, pp. 107-122.

Dunn, K. \& Singh, S. P. (2014) 'Pluralistic conditioning: social tolerance and effective democracy', Democratization, vol. 21, no. 1, pp. 1-28.

Erdemir, A. (2005) 'Tradition and modernity: Alevis' ambiguous terms and Turkey's ambivalent subjects', Middle Eastern Studies, vol. 41, no. 6, pp. 937-951.

Erman, T. \& Göker, E. (2000) 'Alevi politics in contemporary Turkey', Middle Eastern Studies, vol. 36, no. 4, pp. 99-118.

Frølund Thomsen, J. P. (2012) 'How does intergroup contact generate ethnic tolerance? The contact hypothesis in a Scandinavian context', Scandinavian Political Studies, vol. 35, no. 2, pp. 159-178.

Gaertner, S. L. \& Dovidio, J. F. (2000) Reducing Intergroup Bias: The Common Ingroup Identity Model, Psychology Press, Philadelphia: PA.

Gibson, J. L. (1998) 'Putting up with fellow Russians: an analysis of political tolerance in the fledgling Russian democracy', Political Research Quarterly, vol. 51, no. 1, pp. 37-68.

Gibson, J. L. (2006) 'Enigmas of intolerance: fifty years after Stouffer's communism, conformity, and civil liberties', Perspectives on Politics, vol. 4, no. 1, pp. 21-34.

Gibson, J. L. \& Gouws, A. (2003) Overcoming Intolerance in South Africa: Experiments in Democratic Persuasion, Cambridge University Press, Cambridge.

Gunes, C. (2012) The Kurdish National Movement in Turkey: From Protest to Resistance, Routledge, New York, NY.

Gunter, M. M. (2004) 'The Kurdish question in perspective', World Affairs, vol. 166, pp. 197-205.

Gurin, P., Hatchett, S. \& Jackson, J. S. (1989) Hope and Independence: Blacks' Response to Electoral and Party Politics, Russell Sage Foundation, USA.

Gurses, M. (2010) 'Partition, democracy, and Turkey's Kurdish minority', Nationalism and Ethnic Politics, vol. 16, no. 3-4, pp. 337-353.

Gurses, M. (2015) 'Is Islam a cure for ethnic conflict? evidence from Turkey', Politics and Religion, vol. 8, no. 1, pp. 135-154.

Hayes, B. C. \& Dowds, L. (2006) 'Social contact, cultural marginality or economic self-interest? Attitudes towards immigrants in Northern Ireland', Journal of Ethnic and Migration Studies, vol. 32, no. 3, pp. 455-476.

Hindriks, P., Coenders, M. \& Verkuyten, M. (2014) 'Interethnic attitudes among minority groups: the role of identity, contact, and multiculturalism', Social Psychology Quarterly, vol. 77, no. 1, pp. 54-74.

Hodson, R., Sekulic, D. \& Massey, G. (1994)'National tolerance in the former Yugoslavia', American Journal of Sociology, vol. 99, no. 6, pp. 1534-1558.

Hogg, M. A. (2006) 'Social identity theory', In Contemporary Social Psychological Theories, ed P. J. Burke, Stanford University Press, Stanford, CA, pp. 111-136.

Hogg, M. A. (2007) 'Social identity theory', in Encyclopedia of Social Psychology, eds R. F. Baumeister \& K. D. Vohs, Sage, Thousand Oaks, CA, pp. 901-903.

Hutchison, M. L. (2014) 'Tolerating threat? the independent effects of civil conflict on domestic political tolerance', Journal of Conflict Resolution, vol. 58, no. 5, pp. 796-824.

Icduygu, A., Romano, D. \& Sirkeci, I. (1999) 'The ethnic question in an environment of insecurity: the Kurds in Turkey', Ethnic and Racial Studies, vol. 22, no. 6, pp. 991-1010.

Inglehart, R. (2000) 'Culture and democracy', In Culture Matters: How Values Shape Human Progress, eds L. E. Harrison \& S. P. Huntington, Basic Books, New York, NY, pp. 80-98. 
Karakoç, E. (2013) 'Ethnicity and trust in national and international institutions: Kurdish attitudes toward political institutions in Turkey', Turkish Studies, vol. 14, no. 1, pp. 92-114.

Kocher, M. (2002) 'The decline of PKK and the viability of a one-state solution in Turkey', Democracy and Human Rights in Multicultural Societies, vol. 4, no. 1, pp. 128-147.

Kunovich, R. M. \& Hodson, R. (1999) 'Conflict, religious identity, and ethnic intolerance in Croatia', Social Forces, vol. 78, no. 2, pp. 643-668.

Lieberson, S. \& Waters, M. C. (1988) From Many Strands: Ethnic and Racial Groups in Contemporary America, Russell Sage Foundation, New York, NY.

Lijphart, A. (1968) The Politics of Accommodation: Pluralism and Democracy in the Netherlands, University of California Press, Berkeley.

Linz, J. J. \& Stepan, A. C. (1996) 'Toward consolidated democracies', Journal of Democracy, vol. 7, no. 2, pp. 14-33.

Marcus, A. (2007) Blood and Belief: The PKK and the Kurdish Fight for Independence, New York University Press, New York, NY.

McIntosh, M. E., Mac Iver, M. A., Abele, D. G. \& Nolle, D. B. (1995) 'Minority rights and majority rule: ethnic tolerance in romania and Bulgaria', Social Forces, vol. 73, no. 3, pp. 939-967.

McLaren, L. M. (2003) 'Anti-immigrant prejudice in Europe: contact, threat perception, and preferences for the exclusion of migrants', Social Forces, vol. 81, no. 3, pp. 909-936.

Özdemir, B. \& Sarigil, Z. (2015) 'Turkey's Europeanisation process and the Kurdish issue', in The Europeanisation of Turkey: Polity and Politics, eds A. Tekin \& A. Guney, Routledge, New York, NY, pp. 180-194.

Özkırımlı, U. (2014) 'Multiculturalism, recognition and the 'Kurdish question' in Turkey: the outline of a normative framework', Democratization, vol. 21, no. 6, pp. 1055-1073.

Pettigrew, T. F. (1997) 'Generalised intergroup contact effects on prejudice', Personality and Social Psychology Bulletin, vol. 23, no. 2, pp. 173-185.

Pettigrew, T. F. (1998) 'Intergroup contact theory', Annual Review of Psychology, vol. 49, no. 1, pp. 65-85

Pettigrew, T. F. \& Tropp, L. R. (2006) 'A meta-analytic test of intergroup contact theory', Journal of Personality and Social Psychology, vol. 90, no. 5, pp. 751-783.

Pettigrew, T. F. \& Tropp, L. R. (2008) 'How does intergroup contact reduce prejudice? Meta-analytic tests of three mediators', European Journal of Social Psychology, vol. 38, no. 6, pp. 922-934.

Pettigrew, T. F. \& Tropp, L. R. (2011) When Groups Meet: The Dynamics of Intergroup Contact, Psychology Press, Philadelphia, PA.

Popan, J. R., Kenworthy, J. B., Frame, M. C., Lyons, P. A. \& Snuggs, S. J. (2010) ‘Political groups in contact: the role of attributions for outgroup attitudes in reducing antipathy', European Journal of Social Psychology, vol. 40, no. 1, pp. 86-104.

Poyraz, B. (2005) 'The Turkish state and Alevis: changing parameters of an uneasy relationship', Middle Eastern Studies, vol. 41, no. 4, pp. 503-516.

Putnam, R. D. (1993) Making Democracy Work: Civic Traditions in Modern Italy, Princeton University Press, Princeton.

Romano, D. \& Gurses, M., eds (2014) Conflict, Democratisation, and the Kurds in the Middle East: Turkey, Iran, Iraq, and Syria, Palgrave Macmillan, New York, NY.

Rose, R., Mishler, W. \& Haerpfer, C. (1998) Democracy and its Alternatives: Understanding Post-communist Societies, JHU Press, Baltimore, MD.

Sakallioglu, U. C. (1998) 'Kurdish nationalism from an Islamist perspective: the discourses of Turkish Islamist writers', Journal of Muslim Minority Affairs, vol. 18, no. 1, pp. 73-89.

Saracoglu, C. (2009) "Exclusive recognition': the new dimensions of the question of ethnicity and nationalism in Turkey', Ethnic and Racial Studies, vol. 32, no. 4, pp. 640-658.

Sarigil, Z. \& Fazlioglu, O. (2013) 'Religion and ethno-nationalism: Turkey's Kurdish issue', Nations and Nationalism, vol. 19, no. 3, pp. 551-571.

Sarigil, Z. \& Fazlioglu, O. (2014) 'Exploring the roots and dynamics of Kurdish ethno-nationalism in Turkey', Nations and Nationalism, vol. 20, no. 3, pp. 436-458.

Schmitt, M. T. \& Branscombe, N. R. (2002) 'The meaning and consequences of perceived discrimination in disadvantaged and privileged social groups', European Review of Social Psychology, vol. 12, 1, pp. 167-199. 
Sekulić, D., Massey, G. \& Hodson, R. (2006) 'Ethnic intolerance and ethnic conflict in the dissolution of Yugoslavia', Ethnic and Racial Studies, vol. 29, no. 5, pp. 797-827.

Shankland, D. (2003) The Alevis in Turkey: The Emergence of a Secular Islamic Tradition, Routledge, New York, NY.

Snyder, J. (2000) From Voting to Violence: Democratization and Nationalist Conflict, W. W. Norton \& Company, New York, NY.

Stouffer, S. A. (1955) Communism, Conformity, and Civil Liberties: A Cross-section of the Nation Speaks its Mind, Doubleday, Garden City, NY.

Tajfel, H. (1981) Human Groups and Social Categories: Studies in Social Psychology, Cambridge University Press, Cambridge.

Tajfel, H., (1982) 'Social psychology of intergroup relations', Annual Review of Psychology, vol. 33, no. 1, pp. 1-39.

Tajfel, H., \& Turner, J. C. (1979) 'An integrative theory of intergroup conflict', in The Social Psychology of Intergroup Relations, eds W. G. Austin \& S. Worchel, Brooks/ Cole Pub. Co., Monterey, CA, pp. 33-47.

Tajfel, H. \& Turner, J. C. (1986) 'The social identity theory of intergroup behavior', In Psychology of Intergroup Relations, eds S. Worchel \& W. G. Austin, Nelson-Hall, Chicago, IL, pp. 7-24.

Tam, T., Hewstone, M., Kenworthy, J. \& Cairns, E. (2009) 'Intergroup trust in Northern Ireland', Personality and Social Psychology Bulletin, vol. 35, no. 1, pp. 45-59.

Tessler, M. \& Altinoglu, E. (2004) 'Political culture in Turkey: connections among attitudes toward democracy, the military and Islam', Democratization, vol. 11, no. 1, pp. 21-50.

Truman, D. (1951) The Governmental Process: Political Interests and Public Opinion, Alfred A. Knopf, New York, NY.

Van Bruinessen, M. (2000) Kurdish Ethno-Nationalism Versus Nation-Building States: Collected Articles, The Isis Press, Istanbul.

Voci, A. \& Hewstone, M. (2003) 'Intergroup contact and prejudice toward immigrants in Italy: the mediational role of anxiety and the moderational role of group salience', Group Processes \& Intergroup Relations, vol. 6, no. 1, pp. 37-54.

Wagner, U., Christ, O., Pettigrew, T. F., Stellmacher, J. \& Wolf, C. (2006) 'Prejudice and minority proportion: contact instead of threat effects', Social Psychology Quarterly, vol. 69, no. 4, pp. 380-390.

Wagner, U., Van Dick, R., Pettigrew, T. F. \& Christ, O. (2003) 'Ethnic prejudice in East and West Germany: the explanatory power of intergroup contact', Group Processes \& Intergroup Relations, vol. 6, no. 1, pp. 22-36.

Ward, C. \& Masgoret, A. M. (2006) 'An integrative model of attitudes toward immigrants', International Journal of Intercultural Relations, vol. 30, no. 6, pp. 671-682.

Watts, N. F. (2010) Activists in Office: Kurdish Politics and Protest in Turkey, University of Washington Press, Seattle and London.

Wenzel, M., Mummendey, A. \& Waldzus, S. (2007) 'Superordinate identities and intergroup conflict: the ingroup projection model', European Review of Social Psychology, vol. 18, no. 1, pp. 331-372.

Yavuz, M. H. (1998) 'A preamble to the Kurdish question: the politics of Kurdish identity', Journal of Muslim Minority Affairs, vol. 18, no. 1, pp. 9-18.

Yegen, M. (2009) “Prospective-Turks' or' pseudo-citizens': Kurds in Turkey', The Middle East Journal, vol. 63, no. 4, pp. 597-615.

Yeğen, M. (2004) 'Citizenship and ethnicity in Turkey', Middle Eastern Studies, vol. 40, no. 6, pp. 51-66.

Yeşilada, B. A. \& Noordijk, P. (2010) 'Changing values in Turkey: Religiosity and tolerance in comparative perspective', Turkish Studies, vol. 11, no. 1, 9-27. 